ISSN 1816-6075 (Print), 1818-0523 (Online)

Journal of System and Management Sciences

Vol. 11(2021) No.3, pp. 41-57

DOI:10.33168/JSMS.2021.0303

\title{
The Impact of Incentive System on Employees' Entrepreneurship and Innovation Performance: Moderating Effect of Locus of Control
}

\author{
Gandulam Ganbold, Chen Sheng Chen, Muhammad Ayaz, Hyeong-Yu Jang* \\ Department of Business Administration, Gyeongsang National University, Korea \\ gandi_0407@naver.com;c1170336212@163.com; mayaz5404@gmail.com;jmgt21@gnu.ac.kr \\ (corresponding author))
}

\begin{abstract}
The development of new medical procedures and medical services in the environment that has been changed by COVID-19 is indispensable for the improvement of public health. This paper discusses how the concept of incentive systems and employees' entrepreneurship can be applied to achieve innovation performance within a hospital sector in South Korea. The purpose of this study is to examine relationships among the incentive system, employees' entrepreneurship and innovation performance. In addition, the study investigates the moderating effect of locus of control between all of model path. A confirmatory factor analysis validated the measurement model, and subsequently, a structural equation modeling tested the proposed model by using SPSS 26.0, while data were analyzed using AMOS 20.0 statistics software. The result of the paper shows the positive effects of the incentive system on employees' entrepreneurship. Furthermore, employees' entrepreneurship has a significant influence on the product innovation and process innovation. Finally, the moderating effect according to locus of control was partially adopted. The results of the study are expected to suggest academic and practical implications to the private hospital field.
\end{abstract}

Keywords: Incentive system, employees' entrepreneurship, innovation performance, locus of control, private hospital. 


\section{Introduction}

Innovation in hospitals itself is scarcely a new problem. Knowledge and innovation in the area of health are inextricable elements of universal human history. In particular, after the novel coronavirus infection (COVID-19), major changes are expected in the hospital environment and medical service delivery system. After MERS, changes in the hospital infection control system at domestic medical institutions began in earnest, but the recent COVID-19 situation is predicting a transition to a "new normal" with rapid changes across hospitals and medical systems. The process of solving these emerging problems and establishing a longterm infection response system, and the change of public perception through COVID19, are expected to be an opportunity for hospital innovation and medical system improvement in many areas. Therefore, in a rapidly changing life pattern and environment, organizations need to innovate and constantly create new customer value in order to survive and create competitive advantage and achieve sustainable growth. To this end, a creative and innovative entrepreneurship that can use crisis as an opportunity is required. Organizational change and innovation requires all members of the organization to change and innovate (Kim and Oh, 2017). Entrepreneurship means a creative innovation spirit that predicts future changes and challenges novelty, and there are differences in corporate performance depending on entrepreneurship. Entrepreneurship is an important driver of innovation that will enable to provide market opportunities, provide new business opportunities, and create new products and processes (Bailetti, 2012). Moreover, we cannot exclude the importance of employees' entrepreneurship, which indicates a key element for any organization that takes aim at being economical in the knowledge-based international market due to the statistic that it has been viewed as a method encouraging economic growth, innovation and creativity (Boldureanu et al., 2020). A widely-acknowledged fact of organizational innovation is suggested as "Organizational innovation is the formation or implementation, incorporation and taking advantage of value-added uniqueness in economic social setting; modification in the offerings; formation of new techniques for manufacturing, and formation of new management in an organization" (Crossan and Apaydin, 2010). Our current research investigates the relation between employees entrepreneurship and performance innovation (product innovation, process innovation).

However, it has been established that the entrepreneurship of employees is formed by external influence factors rather than by employees themselves, and one of the external factors is the incentive system provided by the organization. Any organization that do not have concern for workers welfare tend to produce less and is vulnerable to failure. Every reward system is based on the assumption that rewarding employees would attract, retain and motivate workers (James et al., 2015). Also, this study attempts to demonstrate the usefulness of personality in explaining human behavior in organizations and focuses on locus of control as it 
relates to behavior in organizational settings.

The purpose of this study aims to verify the relationship between the incentive system, the entrepreneurship of employees, and the organizational product and process innovation performance. In addition, the study investigates the moderating effect of locus of control between all of model path. Above all this study highlights its value and differentiation in that it focused on the incentive system in hospitals, a non-profit organization, and identified its sub-attributes, and that the entrepreneurial orientation of the hospital organization identified the relationship between product innovation and process innovation. In addition, it is also noteworthy that the possibility of practical application was maximized by discriminating all these relationships according to external and internal control tendencies.

\section{Theoretical Background}

\subsection{Incentive System and Employees' Entrepreneurship}

Incentives are forms of payment connected with performance and improvement sharing, as input benefits for organizations due to increased production or cost savings. These are motivating factors for workers to improve their work performance so that operative performance can grow (Yusuf, 2015). Furthermore, the determination of providing incentives is to satisfy the interests of parties preserving a skilled and talented workforce so that reliability is high for the organization, and to maintain and develop employee confidence that is exposed to increase the level of workforce turnover and appearance. Incentives for employees also increase the level of living with acceptance of payments external to the basic salary and escalation of employees' work inspiration to inspire them to perform better (Widhianingrum, 2018).

Hornsby et al. (2002) stressed that that an effective reward system that encourages corporate entrepreneurship must consider goals, feedback, emphasis on individual responsibility, and results-based incentives. Therefore, in this study, the incentive system was defined as a reward paid to members of the organization who achieved the company's goals in relation to the organization's performance. Based on related prior studies, the incentive system in the hospital sector is composed of variables such as money rewards, social rewards, and status rewards, to identify the effect of the incentive system on the entrepreneurship of employees (Yang and Park, 2020). As already reported, these rewards are a vital cause which moves employees' creativity. Different motivating features like bonuses and proper payment rewards have significant connection with greater performance. First, money reward contains issues regarding salary programs wages, commission-based programs and financial supports including discretionary bonuses (Nigusie and Getachew, 2019). Second, status reward officially awards citations to excellent employees who have worked hard in the company. For example, there are good promotion systems according to work performance and good training compensation systems, as well as structures 
increasing from job descriptions (Besley and Ghatak, 2008). The business implications of the indication that human beings have a passion for status have been broadly studied. A key factor of the mission for status arises from the fact that individuals make social evaluations when assessing the price of what they receive. Third, there is a social reward system that provides domestic and foreign training opportunities to outstanding employees who achieve the goals of the organization and provides paid leave for vacation or travel. In addition, medical insurance, medical examinations, and medical support systems, as well as convenience of work environment facilities are well established.

H1: Incentive system has a positive effect on the employees' entrepreneurship.

\subsection{Employees' Entrepreneurship and Innovation System}

Productivity brings new competition through contributing indirectly. In this way, economic growth and national competitiveness is a compound of entrepreneurship (Vicens and Grullón, 2011; Young, 2016). Moreover, in the research field of entrepreneurship, they are given proper attention on how business leadership performance affects business improvement. Actual leadership is presenting the basic source of construct, which develops the platform for the greater trust, for people to develop their strengths, to extend their thoughts, to mature their positive attitudes, to take right decisions, and to improve their skills for better performance in the organization (Avolio, 2005). However, entrepreneurs who are showing their real leadership may definitely be prepared for new challenges and have the potential to face upcoming new business risks; this obviously has a positive impression on employees doing work, and help them appreciate the full strength of their ideas and visualization (Lee and Lew, 2016). Furthermore, although the entrepreneur plays a serious role, it is the employees who achieve and translate the policies and vision of the founder in reality for the business' success and growth.

Entrepreneurship and business venturing, at both individual and firm levels, are becoming an essential part of any innovation ecosystem. The company's corporate entrepreneurial activities directly affects its innovation performance (Kim and Mauborgne, 2005). The increasing pressure from the competitive business environment is making companies improve their decision-making competencies to counter such forces. In order to survive and succeed in this competitive business environment, companies need to adopt innovation, as it is the most appropriate solution to such forces (Kim and Mauborgne, 2005). In the developed economies, the major question is if they need knowledge or advanced knowledge, or technological innovation or marketing innovation. In the developing countries where there are limited investing capabilities, the question then changes into knowledge creation or innovation (Damanpour, 1991). According Hurley, R and Hult, $G$ organizational innovation can make both a procedure and a result or a new structure related to the members of companies (Hurley and Hult, 2018). Additionally, Eom et al. (2018) perceive innovation is the major component of the 
culture of a company and the openness to new concepts. The author showed in the model the capability of organizational innovation which can be stated as the capability of a company to execute novel ideas, procedures or offerings effectively. Therefore, this study attempts to verify organizational innovation by dividing it into product innovation and process innovation based on previous research. First, product innovation is a significant alarm for any organization in order to achieve attractiveness and efficiency. Firms understand that they have to get a handle on current information and innovation to develop new products and make rewards to increase their competitive edge (Yang and Park, 2020). Therefore in this study, in the case of hospitals, product innovation is defined as the degree of competitiveness of medical devices or the degree to which they are often updated with the latest medical equipment and technologies. Second, process innovation is one of the famous 'Theories of Economic Development' in which the author explains the introduction of new products, services or goods, which customers or consumers are not very familiar with from the method of those new products (Simonetti et al., 1995). Process innovations are linked to changes in the way hospitals go about their work; that is, the introduction of new activities such as out-patient services, medical and social services for the destitute, and the development of networks with doctors in private practice and or voluntary organizations (Anatole-Touzet and Souffir, 1996). Based on the literature review this study presents the following hypothesis.

$\mathrm{H} 2$ : Employees entrepreneurship has a positive effect on the product innovation.

H3: Employees entrepreneurship has a positive effect on the process innovation.

$\mathrm{H} 4$ : Product innovation has a positive effect on the process innovation.

\subsection{Locus of Control}

Locus of control is a mental and social wisdom theory that brings up the extension to individual's control over their lives and atmosphere. On the other side, locus of control is a capacity that has relevant control in addition to outcomes. Those who consider themselves capable of controlling their consequences are known to have internal locus of control. Individuals with external locus of control consider their conclusions away from their control (Rotter, 1996; Park and Choi, 2020). Meanwhile, some of the indications provide links between academic literature for the well-being and for the control of internals and externals. The internal control trait means employees believe awards are subject to the results of their actions or property caused by themselves, which they can control. Individuals with external control trait believes that reward is controlled by other external forces, such as other people, fate and opportunities, by which individuals cannot grasp. Therefore, based on previous papers, this study presents the following hypothesis.

H5: Locus of control is the moderator between all of model path

H5a: Locus of control is the moderator between incentive system and employees entrepreneurship. 
H5b: Locus of control is the moderator between employees' entrepreneurship and product innovation.

H5c: Locus of control is the moderator between employees' entrepreneurship and process innovation.

H5d: Locus of control is the moderator between product innovation and process innovation

\section{Research Method}

\subsection{Samples and Research Methodology}

The hospital sector of South Korea is the target of this study. Therefore, this study will focus on the employees in hospitals. Due to time and financial limits, the total questionnaire for this study was given to 246 workers from the hospital sector in Jinju city, South Korea. The data were collected for one month from January 2021 to February 2021 by visit survey.

The SPSS and AMOS statistics is a software package used to analyze the data. AMOS SEM analysis explains the causal relationship among variables to verify the hypothesis, that is to say, to explore the relationship among the incentive system, employees' entrepreneurship, and innovation performance (product innovation, process innovation). Finally, a multi-group analysis was conducted to verify the difference in the research model path according to the locus of control.

\subsection{Major Findings}

Measures: All the constructs were measured using five-point Likert scales anchored by "strongly disagree" and "strongly agree". The items of all constructs were adapted from previous existing scales. Ten items adapted from Yang et al. (2020) were used to measure the incentive system, and nine items adapted from Lim et al. (2019) were used to measure entrepreneurship. The three items adapted from Hameed et al. (2018), three from Sok and Cass (2015) were used to measure product innovation and process innovation performance, respectively. Finally, three items were used to measure locus of control adapted from Rotter (1966) as shown in Table 1.

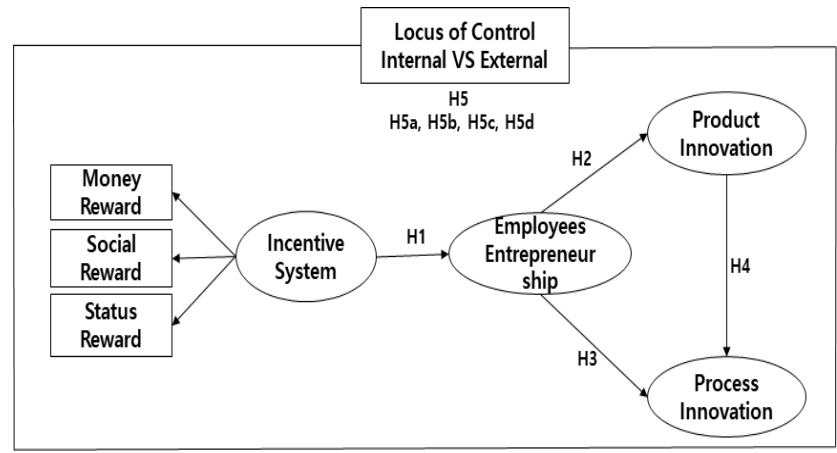

Fig. 1: Research model. 
Table 1: Measurement Item

\begin{tabular}{|c|}
\hline 1. Incentive system \\
\hline 1. Our hospital's wages and allowances are high in the same industry. \\
\hline 2. Our hospital's incentives and bonuses are high in the same industry. \\
\hline $\begin{array}{l}\text { 3. Our hospital's financial support system (ex. monthly rent, scholarships, student funds, } \\
\text { family 4. allowances, etc.) is high in the same industry. }\end{array}$ \\
\hline $\begin{array}{l}\text { 5. Our hospital has a good medical insurance, medical checkup, and medical expenses support } \\
\text { system. }\end{array}$ \\
\hline $\begin{array}{l}\text { 6. Our hospital has good external education support, overseas training, in-house clubs, and in- } \\
\text { house education. }\end{array}$ \\
\hline 7. Our hospital has a good cafeteria, staff rest room, and recreation facilities. \\
\hline 8. Our hospital provides gifts for anniversaries, holiday subsidies. \\
\hline 9. Our hospital has a good promotion system. \\
\hline 10. Our hospital's promotion system based on work performance is not bad. \\
\hline 11. Our hospital has a good training and compensation system. \\
\hline 2. Employee's Innovation (Entrepreneurship) \\
\hline 1. I constantly try to change and innovate. \\
\hline 2. I think innovation in the process of developing new products and services is important. \\
\hline 3. I tend to make efforts to derive innovative results through active communication. \\
\hline Initiative (Entrepreneurship) \\
\hline 4. I tend to contribute to securing our hospital's leading position in the market. \\
\hline 5. I tend to contribute to our hospital's competition with competitive hospitals. \\
\hline $\begin{array}{l}\text { 6. I am active in education or information delivery regarding corporate growth and changing } \\
\text { internal and external environment. }\end{array}$ \\
\hline Autonomy (Entrepreneurship) \\
\hline 7. It is free to share knowledge and ideas among our department employees. \\
\hline 8. I value cooperation among employees to create new ideas. \\
\hline 9. I tend to make efforts to improve new products or service processes and create ideas. \\
\hline 3. Product Innovation \\
\hline 1. Medical equipment and machines used by our hospitals are competitive. \\
\hline $\begin{array}{l}\text { 2. The equipment and machines used by our hospital are often updated with the latest } \\
\text { technology. }\end{array}$ \\
\hline 3. Our hospital introduces the latest equipment and machines relatively quickly. \\
\hline 4. Process Innovation \\
\hline 1. Our hospital uses the latest medical techniques to treat customers. \\
\hline 2. Our hospital uses the latest surgical techniques to operate. \\
\hline 3. Our hospital change in the way hospitals perform work, introduction of new activities. \\
\hline 5. Internal Control \\
\hline 1. Human life depends on effort. \\
\hline 2. Fate is to make it on its own. \\
\hline 3. Ability can be improved as much as possible depending on effort. \\
\hline 6. External Control \\
\hline 1. Things that will happen will happen. \\
\hline 2. It is not easy for a person to change his or her environment. \\
\hline 3. It is not easy for humans to change their fate. \\
\hline
\end{tabular}




\section{Results}

\subsection{The Demographic Characteristics}

Table 2 provides the demographic profile of the respondents who participated in this survey. Out of the usable questionnaires, $211(85.8 \%)$ were from females and $35(14.2 \%)$ were from males. Based on age, $76(30.9 \%)$ of the respondents were 20-29 years old, $70(28.5 \%)$ were between $30-39$ years old, 66(26.8\%) were between 40-49 years old, and 34(13.8\%) were 50 years old or over. In addition, most of the respondents (a total of 154, 62.6\%) were working in a department as a nurse or nurse's assistant. Moreover, the respondents' working periods were mainly less than 5 years which was equivalent to $110(44.7 \%)$ respondents.

Table 2: Respondents' demographic profiles.

\begin{tabular}{|c|c|c|c|}
\hline Demographics & Categories & $\begin{array}{c}\text { Frequency } \\
(\mathbf{N}=\mathbf{2 4 6})\end{array}$ & Percentage (\%) \\
\hline \multirow{2}{*}{ Gender } & Male & 35 & $14.2 \%$ \\
\hline & Female & 211 & $85.8 \%$ \\
\hline \multirow{4}{*}{ Age } & $20-29$ & 76 & $30.9 \%$ \\
\hline & $30-39$ & 70 & $28.5 \%$ \\
\hline & $40-49$ & 66 & $26.8 \%$ \\
\hline & 50 and over & 34 & $13.8 \%$ \\
\hline \multirow{4}{*}{ Department } & Doctor & 13 & $5.3 \%$ \\
\hline & Administration & 50 & $20.3 \%$ \\
\hline & Nurse, nurse's assistant & 154 & $62.6 \%$ \\
\hline & Other & 29 & $11.8 \%$ \\
\hline \multirow{4}{*}{ Working period } & Less than 5 years & 110 & $44.7 \%$ \\
\hline & $5-10$ years & 36 & $14.6 \%$ \\
\hline & $10-15$ years & 34 & $13.8 \%$ \\
\hline & More than 15 years & 66 & $26.8 \%$ \\
\hline
\end{tabular}

\subsection{Reliability Analysis}

Reliability refers to the degree of questionnaire consistency; it represents the consistency of scores obtained by the same group of subjects when answering questions in the questionnaire, where credibility and stability can be from the test scores. In the reliability analysis test, the most common is the internal consistency reliability, which was also used to analyze the Cronbach's alpha as shown in Table 3. The Cronbach's alpha was .869 for money reward, .724 for social reward, and .883 for status reward. The Cronbach's alpha was .915 for entrepreneurship, .934 for product innovation and .881 for process innovation. Finally, for locus of control, the Cronbach's alpha was .915. Therefore, the Cronbach's coefficient $\alpha$ estimates for seven variables were more than .70 , which was considered acceptable. 
Table 3: Reliability analysis

\begin{tabular}{|c|c|c|c|}
\hline \multicolumn{2}{|c|}{ Construction } & Items & Cronbach's $\alpha$ \\
\hline \multirow{3}{*}{$\begin{array}{c}\text { Incentive } \\
\text { System }\end{array}$} & Money Reward & 3 & .869 \\
\cline { 2 - 4 } & Social Reward & 4 & .724 \\
\cline { 2 - 4 } & Status Reward & 3 & .883 \\
\hline \multicolumn{2}{|c|}{ Employee's Entrepreneurship } & 9 & .915 \\
\hline \multirow{2}{*}{$\begin{array}{c}\text { Innovation } \\
\text { Performance }\end{array}$} & Product Innovation & 3 & .934 \\
\cline { 2 - 4 } & Process Innovation & 3 & .881 \\
\hline \multicolumn{2}{|c|}{ Locus of Control } & 3 & .915 \\
\hline
\end{tabular}

\subsection{Confirmatory Factor Analysis}

The measurement model was evaluated, and convergent validity was assessed using loadings, average variance extracted (AVE) and composite reliability (CR). For models with goodness of fit to data, the values were the following: $\mathrm{CMIN}=335.321$, $\mathrm{CMIN} / \mathrm{df}=1.247, \mathrm{CFI}=.883, \mathrm{TLI}=.859, \mathrm{IFI}=.894, \mathrm{NFI}=.624, \mathrm{GFI}=.895, \mathrm{AGFI}=.863$ $\mathrm{RMR}=.051, \mathrm{RMSEA}=.044$. Most of the factor loadings exceeded the recommended value of .60 for all items. In addition, all of the $C R$ values exceeded the recommended value of .70. According to the analysis, CR values were found to be .7(.748 .952) and AVE values over .5(.597 .845) for all variables. Also, all of the AVE values for all under-study constructs were beyond the recommended values of .50. Nevertheless, the seven question items MR3, SCLR1, SCLR2, STSR3, and EPSHIP7 were deleted based on a (.50) value. The result of the confirmatory factor analysis (CFA) is shown in Table 4.

\subsubsection{Second order confirmatory factor analysis}

The analysis continued with the examination of the second order CFA. In the case of a second order CFA, the lower level variables are latent variables which have effects on their measured indicators. As shown in Figure 2, the three identified variables of the incentive system were found to have adequate goodness of fit. The model fit index was chi-square statistics, $\chi^{2}=7.574, \mathrm{DF}=6, \mathrm{p}=.000 \mathrm{GFI}=.991$, AGFI=.964, NFI=.959, IFI=.991, TLI=.977, $\mathrm{CFI}=.991, \quad \mathrm{RMR}=.012, \quad$ and RMSEA $=.033$ respectively. In addition, most of the factor loadings exceeded the recommended value of .60 for all items. Therefore, it is concluded that the overall assessment of the criteria for model fit was acceptable for the six items incentive system scale using second order confirmatory factor analysis in its validation. Figure 2 below shows the details. 
Table 4: Confirmatory factor analysis

\begin{tabular}{|c|c|c|c|c|c|c|}
\hline Items & Estimate & S.E. & C.R. & $p$ value & C.R & AVE \\
\hline Moneyreward1 & .894 & - & - & - & \multirow[b]{2}{*}{.883} & \multirow[b]{2}{*}{.791} \\
\hline Moneyreward2 & .885 & .071 & 14.588 & $* * *$ & & \\
\hline Socialreward3 & .746 & - & - & - & \multirow[b]{2}{*}{.748} & \multirow[b]{2}{*}{.597} \\
\hline Socialreward4 & .799 & .135 & 9.833 & $* * *$ & & \\
\hline Statusreward1 & .860 & - & - & - & \multirow[b]{2}{*}{.808} & \multirow[b]{2}{*}{.893} \\
\hline Statusreward2 & .936 & 0.073 & 14.978 & $* * *$ & & \\
\hline Entrepreneurship1 & .789 & - & - & - & \multirow{8}{*}{.952} & \multirow{8}{*}{.715} \\
\hline Entrepreneurship2 & .754 & .086 & 10.863 & $* * *$ & & \\
\hline Entrepreneurship3 & .862 & .07 & 14.863 & $* * *$ & & \\
\hline Entrepreneurship4 & .887 & .08 & 13.27 & $* * *$ & & \\
\hline Entrepreneurship5 & .936 & .092 & 13.349 & $* * *$ & & \\
\hline Entrepreneurship6 & .882 & .088 & 12.661 & $* * *$ & & \\
\hline Entrepreneurship8 & .785 & .092 & 9.849 & $* * *$ & & \\
\hline Entrepreneurship9 & .855 & .079 & 12.763 & $* * *$ & & \\
\hline PoductInnovation1 & .878 & - & - & - & \multirow{3}{*}{.942} & \multirow{3}{*}{.845} \\
\hline PoductInnovation2 & .942 & .051 & 21.311 & $* * *$ & & \\
\hline PoductInnovation3 & .936 & .054 & 19.682 & $* * *$ & & \\
\hline ProcessInnovation3 & .748 & - & - & - & \multirow{3}{*}{.890} & \multirow{3}{*}{.732} \\
\hline ProcessInnovation2 & .883 & .084 & 13.202 & $* * *$ & & \\
\hline ProcessInnovation1 & .926 & .098 & 12.805 & $* * *$ & & \\
\hline Locus of Conrol1 & .840 & - & - & - & \multirow{3}{*}{.912} & \multirow{3}{*}{.777} \\
\hline Locus of Control2 & .940 & .067 & 16.424 & $* * *$ & & \\
\hline Locus of Control3 & .861 & .067 & 14.858 & $* * *$ & & \\
\hline
\end{tabular}




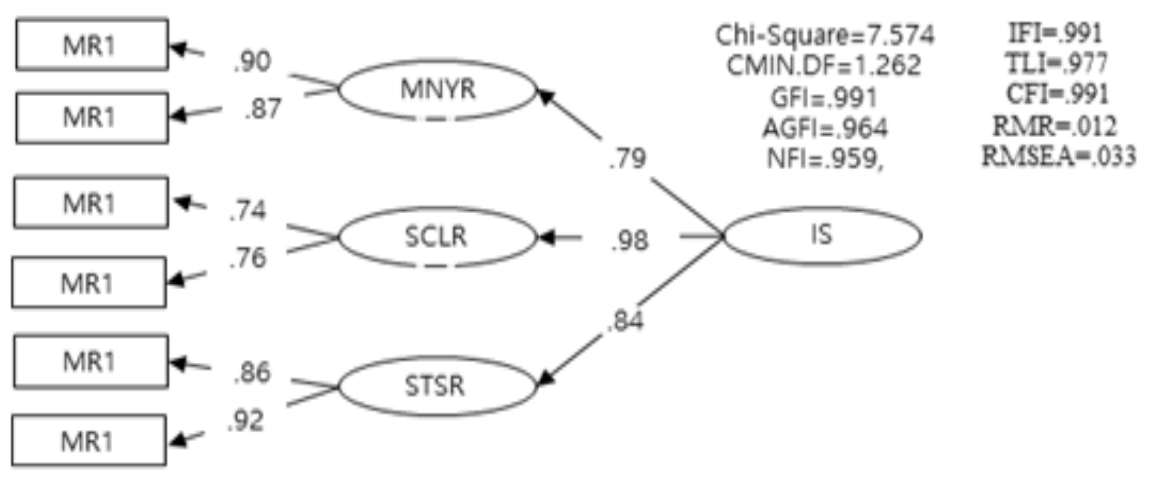

Fig. 2: Result for second order CFA.

Abbreviation: $\mathrm{MR}=$ Money Reward, SCLR $=$ Social Reward, STSR $=$ Status Reward, EPSHIP= Entrepreneurship, PRO IN=Product innovation, PRCS $\mathrm{IN}=$ Process innovation, $\mathrm{L}$ of $\mathrm{Ctrl}=$ Locus of control.

\subsubsection{Correlation analysis}

The correlations among the variables were analyzed as shown in Table 5. The comparison of AVE square root was higher than correlation. As a result of comparing the correlation of all two variables and square root value of AVE, the correlation value is lower than the square root value of all AVEs. In addition, no pair of measures was found with correlation that exceeds the 0.9 , indicating no multi-collinearity exists among the constructs.

Table 5: Correlation analysis

\begin{tabular}{|c|c|c|c|c|c|c|c|}
\hline Items & MR & SCR & STSR & EPSHIP & PRO IN & PRCS IN & L of Ctrl \\
\hline MR & $\mathbf{. 7 9 1}$ & & & & & & \\
\hline SCR & .565 & $\mathbf{. 5 9 7}$ & & & & & \\
\hline STSR & .450 & .586 & $\mathbf{. 8 9 3}$ & & & & \\
\hline EPSHIP & .121 & .196 & .158 &. $\mathbf{7 1 8}$ & & & \\
\hline PRO IN & .127 & .168 & .115 & .264 & $\mathbf{. 8 4 5}$ & & \\
\hline PRCS IN & .115 & .187 & .132 & .392 & .728 & .732 & \\
\hline L of Ctrl & .019 & .044 & .030 & .331 & .157 & .201 &. $\mathbf{7 7 1}$ \\
\hline
\end{tabular}

Notes: * The square root of Ave value is in bold type on diagonal. *p<0.01

\subsubsection{Path analysis}

The results of the path analysis are shown in Table 6 . The values of model fit indices chi-square $=200.453, \mathrm{D} / \mathrm{F}=156, \mathrm{p}=.000, \mathrm{GFI}=.918, \mathrm{AGFI}=.890, \mathrm{RMR}=.067$, RMSEA=.034 were above the threshold values and indicates a good model fit. Therefore, hypotheses testing through path analysis were appropriate to proceed. As shown in Table 5, four hypotheses (H1, H2, H3, H4) are supported. In H1, incentive system had a significant positive direct effect on employee's entrepreneurship of a 
firm $(\beta=.470, \mathrm{P}<.001)$. In $\mathrm{H} 2$, employees entrepreneurship had a positive direct effect on product innovation $(\beta=.521, p<.001)$. In H3, employees entrepreneurship had a positive direct effect on process performance $(\beta=.270, p<.001)$. In H4, product innovation also had a positive direct effect on process innovation of a firm $(\beta=.694, p<.001)$.

Table 6: Path analysis

\begin{tabular}{|c|c|c|c|c|c|}
\hline Hyp. & Relationship & Estimate & S.E. & C.R. & $p$ value \\
\hline H1 & Incentive System $\rightarrow$ Entrepreneurship & .470 & .087 & 5.507 & $\begin{array}{c}\text { Supported } \\
* * *\end{array}$ \\
\hline H2 & Entrepreneurship $\rightarrow$ Product Innovation & .521 & .092 & 6.886 & $\begin{array}{c}\text { Supported } \\
* * *\end{array}$ \\
\hline H3 & Entrepreneurship $\rightarrow$ Process Innovation & .270 & .051 & 4.435 & $\begin{array}{c}\text { Supported } \\
* * *\end{array}$ \\
\hline H4 & $\begin{array}{c}\text { Product Innovation } \rightarrow \text { Process } \\
\text { Innovation }\end{array}$ & .694 & .053 & 8.999 & $\begin{array}{c}\text { Supported } \\
* * *\end{array}$ \\
\hline CMIN=200.453, df=156, CMIN/DF=1.285, GFI=.918, AGFI=.890, NFI=.699, IFI=.913, \\
TLI=.886, CFI=.906, RMR=.067, RMSEA=.034
\end{tabular}

\subsection{Testing Locus of Control as A Moderator}

The study investigates locus of control as a moderator of the relationships among incentive system, employees' entrepreneurship, product innovation, and process innovation. The result received partial support. In order to examine the differences according to locus of control, a multi-group analysis was conducted by dividing into an internal control group $(n=146)$ and an external control group $(n=100)$ based on the mean value (mean $=3.58$ ). As a result of the analysis, Hypothesis 5a, the effect of incentive system on employees entrepreneurship will vary according to locus of control, the path coefficient was $\left(\Delta \chi^{2} /(\mathrm{df}=1)=3.147, p>.10\right)$, and the significance level was $10 \%$, therefore the hypothesis was adopted. Hypothesis $5 \mathrm{~b}$, the effect of employees entrepreneurship on product innovation will vary according to locus of control, the path coefficient was $\left(\Delta \chi^{2} /(\mathrm{df}=1)=.087, p<.05\right)$, thus the hypothesis was rejected. In addition, Hypothesis $5 \mathrm{c}$, the effect of employees entrepreneurship on process innovation will vary according to locus of control, the path coefficient was $\left(\Delta \chi^{2} /(\mathrm{df}=1)=.055, p<.05\right)$, and therefore the hypothesis was rejected. Finally, for Hypothesis $5 \mathrm{~d}$, which states that the effect of product innovation on process innovation will vary according to locus of control, the path coefficient was $\left(\Delta \chi^{2} /(\mathrm{df}=1)=4.223, p>.05\right)$, and the hypothesis was adopted. 
Table 7: Multi-Group analysis

\begin{tabular}{|c|c|c|c|c|c|c|}
\hline \multirow[t]{2}{*}{ Hyp. } & \multirow[t]{2}{*}{ Relationship } & $\begin{array}{c}\text { Internal } \\
\mathrm{N}=146\end{array}$ & $\begin{array}{c}\text { External } \\
\mathbf{N}=100\end{array}$ & \multirow{2}{*}{$\begin{array}{c}\text { Free } \\
\text { Model }\end{array}$} & \multirow[t]{2}{*}{$\begin{array}{l}\text { Default } \\
\text { Model }\end{array}$} & \multirow{2}{*}{$\begin{array}{c}\Delta \chi^{2} \\
(\Delta \mathbf{d f}=\mathbf{1}) \\
\text { Result }\end{array}$} \\
\hline & & loading & loading & & & \\
\hline $\mathrm{H} 5 \mathrm{a}$ & $\begin{array}{c}\text { Incentive System } \rightarrow \\
\text { Entrepreneurship } \\
\end{array}$ & $\begin{array}{c}.213 \\
(1.885) \\
\end{array}$ & $\begin{array}{c}.622 \\
(4.245) \\
\end{array}$ & \multirow{4}{*}{441.792} & 444.938 & $\begin{array}{c}3.147 \\
(.076) *\end{array}$ \\
\hline $\mathrm{H} 5 \mathrm{~b}$ & $\begin{array}{l}\text { Entrepreneurshi } p \rightarrow \\
\text { Product Innovation }\end{array}$ & $\begin{array}{c}.270 \\
(2.545) \\
\end{array}$ & $\begin{array}{c}.447 \\
(3.203) \\
\end{array}$ & & 441.879 & $\begin{array}{c}.087 \\
(.768) \\
\end{array}$ \\
\hline $\mathrm{H} 5 \mathrm{c}$ & $\begin{array}{l}\text { Entrepreneurship } \rightarrow \\
\text { Process Innovation }\end{array}$ & $\begin{array}{c}.249 \\
(2.807) \\
\end{array}$ & $\begin{array}{c}.144 \\
(1.358) \\
\end{array}$ & & 441.847 & $\begin{array}{c}.055 \\
(.814) \\
\end{array}$ \\
\hline H5d & $\begin{array}{c}\text { Product Innovation } \\
\rightarrow \text { Process } \\
\text { Innovation }\end{array}$ & $\begin{array}{c}.689 \\
(5.384)\end{array}$ & $\begin{array}{c}.757 \\
(4.959)\end{array}$ & & 446.015 & $\begin{array}{c}4.223 \\
(.040) * *\end{array}$ \\
\hline & **Significance level & $(1) \gtreqless$ & *Signifi & & $\chi^{2}(1)$ & \\
\hline
\end{tabular}

\section{Conclusion and Discussion}

This study aimed to empirically identify the relationship between employees entrepreneurship and organization innovation performance (product innovation, process innovation) of the incentive system (money reward, social reward, status reward) for hospital staff in South Korea. Based on the existing literature and research, three latent variables for the incentive system were extracted. In addition, by dividing the locus of control into internal control and external control, the difference in the influence relationship of each model route according to the locus of control was verified. The findings and implications are as follows.

First, Hypothesis 1 was adopted. It was found that the incentive system had a positive effect on the employees' entrepreneurship (Gandulam et al., 2021). The outcome of the second order CFA analysis show that incentives consisted of three factors. In particular, social reward was the most important factor in explaining the incentive system. The results of this study show that that employees want organizations with well-equipped medical insurance, regular health check-ups, and medical expenses support systems because of improved living standards and an aging population. It also shows that the organizational incentive system, which provides opportunities to improve competency through external education expenses support, overseas training, and internal education, has become more important. It also shows that the convenience of the work environment, such as restaurants, employee rest rooms, and fully-equipped facilities in the organization, has a positive impact on employees' entrepreneurship and can achieve good results. Next, the status reward is an important factor in shaping the entrepreneurship of employees. Therefore, it shows that hospitals providing a good promotion system based on employees performance and giving all employees a chance to compete fairly has a positive impact on their entrepreneurship. Finally, money reward did not have a 
large explanatory power for the incentive system, but it is a factor that influences it. In addition to the financial bonus system according to work performance, encouraging employees in various aspects, such as family allowance and monthly rent, has a better effect on enhancing the entrepreneurship of employees.

Second, Hypothesis 2 and 3 were adopted. Employees' entrepreneurship appears to have a positive impact on hospital product innovation and process innovation. This result shows that the entrepreneurship of employees has a significant role in shaping organizational innovation performance, and shows the same results as previous studies that it forms an organizational innovation through entrepreneurship. Previous studies have usually conducted a lot of research on innovation performance focusing on the entrepreneurship of organization managers, and this study has a distinction from the previous studies in that it studied the entrepreneurship of employees by segmenting them into the sectors of hospitals.

Third, Hypothesis 4, which stated that product innovation has a positive effect on process innovation, was also supported. These results show that in order to achieve service innovation, product innovation must first be backed up. Especially for hospitals, new activities such as service innovation linked to changes in work progress, outpatient services, introduction of new medical services, and development of networks with private doctors will be possible only when medical facilities are equipped and creative and innovative ideas exist.

Finally, Hypotheses 5a, 5b, 5c and 5d, which stated that the coefficients of individual pathways in the model would differ depending on the internal and external control of employees, were all partially adopted. Hypothesis $5 \mathrm{~b}$ and $5 \mathrm{c}$ were rejected. Therefore, this shows that once entrepreneurship has been formed, the results of the organizational innovation performance resulting from entrepreneurship cannot be changed easily due to further external factors. Therefore, in order to maximize the innovation performance of hospitals, the most important thing is the process of forming entrepreneurship so that each employee can work in the position of the organization manager. However, since the incentive system within the organization plays an important role in the entrepreneurship of employees, providing an environment in which employees can further develop their own capabilities, especially starting with social welfare incentives, is recommended.

On the other hand, Hypothesis 5a was supported at the significance level of $10 \%$. In other words, the influence of the incentive system on the employees' entrepreneurship was found to be more influenced by external control than internal control. Also, Hypothesis 5d was supported. It was found that the effect of product innovation on service innovation differs depending on the internal and external control of employees. In other words, the impact of product innovation on process innovation appears to be greater when it is influenced by external control rather than internal control. It can be inferred that the case of making decisions based on external control power based on various information generally has a high capacity 
for coordinating decision-making according to the situation. However, it can be presumed that if the progressive tendency exerts an influence on process innovation, it puts a greater weight on the external control based on the ego rather than the external control based on external information.

There are still limitations that could be addressed in future research. This study and the model have been applied to two hospitals in the health sector in Jinju city, South Korea. Using data across different regions and multiple hospitals (university hospitals) would help generalize stronger results. In addition, ethical issues have recently emerged, but this study did not consider these parts well.

\section{References}

Anatole-Touzet, V., and Souffir, W. (1996). Innovation technologique, organisation du travail et gestion des compétences. Gestions hospitalières, 354, 222-225.

Avolio, B. J. (2005). Leadership development in balance: Made/Born. Psychology Press.

Bailetti, T. (2012). Technology entrepreneurship: overview, definition, and distinctive aspect. Journal of Technology Innovation Management Review, 2(2), 512.

Besley, T., and Ghatak, M. (2008). Status incentives. American Economic Review, 98(2), 206-211.

Boldureanu, G., Ionescu, A. M., Bercu, A. M., Bedrule-Grigoruţă, M. V., and Boldureanu, D. (2020). Entrepreneurship education through successful entrepreneurial models in higher education institutions. Sustainability, 12(3), 1267.

Crossan, M. M., and Apaydin, M. (2010). A multi-dimensional framework of organizational innovation: A systematic review of the literature. Journal of Management Studies, 4(6), 1154-1191.

Damanpour, F. (1991). Organizational innovation: a meta-analysis of effects of determinants and moderators. The Academy of Management Journal, 34(3), 555590 .

Eom, S., Hwang, H., and Kim, J. (2018). Can social media increase government responsiveness? A case study of Seoul, Korea. Government Information Quarterly, 35(1), 109-122. 
Gandulam, G., Muhammad, A., Chen, S., Hyeong, Y. J. (2021). The effects of the incentive system on employees' entrepreneurship and innovation performance: moderating effect of locus of control. World Journal of Accounting, Finance and Engineering, 5(1).

Hameed, W. U., Sabir, A., Razzaq, S., Humanyon, A. (2018). The influence of behavioural biases on investment decision making: A moderating role of religiosity among Pakistani investors. International Journal of Management Research and Emerging Sciences, 8(1), 87-98.

Hornsby, J. S., Kuratko, D. F., and Zahra, S. A. (2002). Middle managers' perception of the internal environment for corporate entrepreneurship: assessing a measurement scale. Journal of Business venturing, 17, 253-273.

Hurley, R., and Hult, G. (2018). Innovation, market orientation, and organizational learning: an integration and empirical examination. The Journal of Marketing, 62(3), 42-54.

James, O. E., Ella, R., Nkamare, S. E., Lukpata, F. E., and Uwa, S. L. (2015). Effect of reward system among health care workers performance: a case study of university of Calabar teaching hospital Calabar, Nigeria. Journal of Hospital Administration, 12(3), 1267.

Kim, W. C., and Mauborgne, R. (2005). Blue ocean strategy: from theory to practice. California Management Review, 47(3), 105-121.

Kim, Y., and Oh, Y. (2017). A study on the effects of CEO's entrepreunership on the firm's financial performance: focused on the mediation effect of csr activities. Academic Society of Global Business Administration, 14(5), 303-331.

Lee, K., and Lew, K. (2016). A study of teaching core competencies for improving creativity. Asia-Pacific Journal of Educational Management Research, 1(1), 161166.

Lim, J., Kong, S., and Oh, S. (2019). The effect of entrepreneurship on innovation and management performance: focus on the 5 star hotels in Seoul. Journal of Hospitality and Tourism Studies, 21(4), 114-130.

Nigusie, G. T., and Getachew, H. (2019). The effect of reward system on employee creativity. Journal of Higher Education Service Science and Management, 2(1). 
Park, S., and Choi, B. (2020). Empathy, self-efficacy, and nursing performance of nurses at care hospitals. International Journal of Advanced Nursing Education and Research, 5(1), 63-70.

Rotter, J. B. (1966). Generalized expectancies for internal versus external control of reinforcements. Psychological Monographs, 80(1), 28.

Simonetti, R., Archibugi, D., and Evangelista, R. (1995). Product and process innovations: how are they defined? How are they quantified. Scientometrics, 32(1), 77-89.

Sok, P., and Cass, A. O. (2015). Achieving service quality through service innovation exploration-exploitation: The critical role of employee empowerment and slack resources. Journal of Services Marketing, 29(2), 137-149.

Vicens, L., and Grullón, S. (2011). Innovation and entrepreneurship: A model based on entrepreneur development. Discussion Papers, Inter-American Development Bank: Capital Markets and Financial Institutions Division, IDB-DP-202.

Widhianingrum, W. (2018). The effect of giving incentives to employee performance PT. BPR Ekadharma Magetan. International Journal of Economics, Business and Accounting Research, 2(4).

Yang, J. Y., and Park, Y. J. (2020). The effect of incentive systems on organizational loyalty, business performance, and corporate performance: A focus on resort employees. International Journal of Tourism and Hospitality Research, 34(1), 87-101.

Young, J. H. (2016). The impact of the creative atmosphere of a group and individual motivation on a university student's creative personality. Asia-Pacific Journal of Educational Management Research, 1(1), 23-28.

Yusuf, B. (2015). Human resource management in Islamic Financial Institutions. Cet. 1, Jakarta. Rajawali Press. 